\title{
Making Space for the Gods: Ethnographic Observations of Chinese House Temples in Singapore
}

\author{
Shawn Goh Ze Song \\ Lee Kuan Yew School of Public Policy, National University of Singapore, Singapore 119077, Singapore; \\ shawn.goh@nus.edu.sg
}

Received: 25 May 2020; Accepted: 8 July 2020; Published: 10 July 2020

\begin{abstract}
Space for religious use is highly regulated in Singapore. Specific plots of land are reserved for religious groups to bid for, and create, "official" spaces of worship. However, religious practices continue to exist within "unofficial" sacred spaces, such as house temples and wayside shrines, negotiating and resisting the overt management of religion by the Singapore state. Scholars, including Vineeta Sinha and Terence Heng, demonstrate how sacrality infused into everyday secular urban spaces defies neat binaries of "sacred/profane" and "legal/illegal", and how Chinese house temples or sintuas-temples located within public housing flats—sustain sacred spaces, despite being technically illegal under housing regulations. Drawing upon a series of ethnographic observations conducted over a year of four sintuas and their activities in Singapore, this paper explores the different ways through which sintuas produce sacred space as a response to spatial constraints imposed by the state. These include (1) re-enchanting everyday urban spaces during a yewkeng-a procession around the housing estate-with the help of a spirit medium; (2) using immaterial religious markers (e.g., ritual sounds and smells) to create an "atmosphere" of sacredness; (3) appropriating public spaces; and (4) leveraging the online space to digitally reproduce images of the sacred.
\end{abstract}

Keywords: Singapore; unofficial sacred spaces; Chinese house temples; spirit mediums; ethnography

\section{Introduction}

Space is highly and systematically regulated in Singapore. Since its independence, the Singapore state has been preoccupied with economic development, modernization, and nation building. "Land scarcity" has often been used as part of the dominant narrative to justify the careful and judicious use of available land to achieve these state-defined objectives. Singaporeans are also persuaded to trust that the state's decisions pertaining to the spatial ordering and bureaucratic control of land are rational, sound, and for the better good of the country (Mahizhnan and Lee 2002). For instance, the loss of heritage buildings (e.g., Pearl Bank Apartments) or community spaces (e.g., Sungei Road Thieves Market) as part of urban renewal is often framed as an inevitable outcome of "tough but necessary decisions" to keep Singapore relevant and competitive in the 21st century. Scholars have also demonstrated how this control over space allows the state to extend its influence to, and intervene in, other spheres of life, such as the economy (Shatkin 2014), race and ethnic relations (Lai 2004; Ooi et al. 1993), as well as religious matters (Goh 2016; Lim 2012; Pereira 2016).

The state regulation of religious space in Singapore has resulted in what some scholars conceptualise as "official" and "unofficial" sacred spaces. "Official" sacred spaces are approved by the state, whereas "unofficial" sacred spaces are produced through alternative ways of acquiring space for the sacred, in response to being unable to secure "official" ones. Chinese house temples (or sintuas), the focus of inquiry in this paper, are an example of such "unofficial" sacred spaces. Operating illegally in public housing flats, sintuas face the challenge of having to produce and sustain sacred space to fulfil religious needs, yet do so in a way that allows them to evade undesired attention from the state. In this 
paper, I argue that it is precisely this spatial precarity of sintuas that makes the temporary, transient, impermanent, and immaterial modes of producing sacred space imperative to sintuas, and worthy of scholarly attention, as such qualities enable sintuas to better manage spatial challenges. I present four such instances, namely, (1) temporarily re-enchanting everyday urban spaces; (2) creating an atmosphere of sacredness through immaterial religious markers; (3) appropriating secular urban spaces for religious merriment; and (4) leveraging the online space to digitally reproduce the image of the sacred.

\section{Ethnographic Participant Observation as Method}

The approach I have taken for this study is ethnographic in nature, and the material presented in this paper has been generated from fieldwork conducted in four sintuas in Singapore, between December 2017 and December 2018. I made conscious efforts to conduct field visits to these sintuas on various occasions-e.g., regular spiritual consultation sessions and major religious occasions like deities' birthdays-in order to get a broader understanding of sintuas and their activities. These four sintuas were not deliberately chosen for particular characteristics they possessed to fit my research agenda, but instead selected after introduction by gatekeepers in the field, as well as after serendipitous "stumbling upon". This resembles what the anthropologist George Marcus (1995) described as "mobile ethnography" - "ethnography that takes unexpected trajectories in tracing a cultural formation across and within multiple sites of activity" (Marcus 1995, p. 96). It also shares some semblance to Anna Tsing's idea of "patchwork ethnography", where "ethnographic fragments" gathered from multiple sites are collected and pieced together, to make connections that are complex and at times contradictory (Lopes 2016). The ethnographic method also emphasizes immersion in the field, often for extended periods of time, in order to tease out nuances and grasp in-depth understandings of the field. Having done only a year of fieldwork, I do not claim to have achieved this "ethnographic gold standard". Instead, I present my findings as exploratory and preliminary, but nonetheless, informative in guiding future research.

I have relied largely on the ethnographer's method of participant observation in my fieldwork. Leading anthropologist, Harry Wolcott, characterizes ethnography as a "way of seeing", which involves not only the "looking at" and "observing", but also the interpretive aspects of "conceptualizing" and "understanding" (Wolcott 2008). Wolcott (2008) talks about the "ethnographer as instrument", where the ethnographer experiences fieldwork, as a dynamic interaction of the visual, aural, olfactory, and other sensorial stimulations, is inevitably intertwined with the process of meaning-making and analyzing what is being observed. However, while participant observation constitutes an integral part of the ethnographic method, that in itself does not equate to a full-scale ethnography. The intersection between participant observation and the narratives collected through in-depth interviews and informal conversations is what produces "thick descriptions" of field experiences (Geertz 2008). While I have not presented valuable insights collected from informal conversations in the field here as a form of data, they have, nonetheless, shaped the sense-making of my observations.

In addition to ethnographic participant observation, I also adopt Sinha's (2016) method of "tracking signs of the sacred" as a guiding frame of analysis. In her ethnography of religious spaces in Singapore, Sinha (2016) argues that sacred spaces have typically been regarded as "places of worship", where the divine is represented outwardly, taking physical, material, and architectural forms, such as "shrines, altars, temples, churches, gurdwaras, and mosques" (Sinha 2016, p. 470). However, Sinha (2016) distinguishes these "places of worship" from what she describes as "signs of the sacred"—indicators of the sacred that have been inserted, embedded, and infused into everyday secular spaces, thus marking them as sacred. Sinha (2016) argues that her method "enables a more inclusive mapping of the field as it captures ostensibly secular spaces which are marked by sacred signs and thus seen to be efficacious" (Sinha 2016, p. 470). I found Sinha's inclusive approach valuable in helping me to pay close attention to the production of sacred space that bears qualities of being temporary, transient, impermanent, and immaterial. 
With regard to ethics, I have made it a point to disclose my identity as a researcher whenever in the field. I was fortunate to be granted access to these spaces, as well as the permission to take photographs as part of my data collection. I have also chosen to anonymize the names of places and actors in this paper to minimize any risk of exposing them to the authorities and putting them in a vulnerable position.

\section{Spatial Regulation of Religion and Its Implications}

Singapore has a population that is diverse in its religiosity. According to the Department of Statistics' General Household Survey (2015), 43.2\% of Singapore's residents identify with Buddhism/Taoism; $18.8 \%$ identify with Christianity; $14.0 \%$ identify with Islam; $5.0 \%$ identify with Hinduism; and $0.6 \%$ identify with other religions such as Sikhism and the Bahai Faith. Scholars including Lily Kong (1993b), Eugene Tan (2008), and Orlando Woods (2018) argue that this religious heterogeneity has compelled the state to adopt a secular position that does not privilege any one religious group, and treats all recognized religions equally and fairly. In particular, Kong (1993b) identifies four principles that underpin the state's secular stance-(1) Singapore is a secular state without an official state religion; (2) the state allows the freedom of worship; (3) there is an official commitment to multiculturalism and all religious groups are treated equally and fairly without discrimination, regardless of being the majority or minority in numbers; (4) religion and politics are kept strictly separate, in the sense that religious groups should not venture into politics, and political parties should not use religious sentiments to gain popular support.

To uphold these principles and safeguard religious harmony, the state introduced various regulatory measures. For instance, legislations, such as the Maintenance of Religious Harmony Act and Sedition Act, allow the government to take action against anyone whose actions or words cause feelings of enmity and hatred between religious groups (Ng 2017; Tan 2008). Under the Societies Act, religious groups of 10 or more persons are required to register with, and provide regular updates about their activities to, the Registrar of Societies, which comes under the purview of the Ministry of Home Affairs (Tan 2008).

On top of legal provisions, the zoning and regulation of space is another key strategy through which the state maintains control over religious groups and religious spaces in Singapore. To ensure adequate space for religious activities while accommodating the other competing demands for land, specific parcels of land are zoned "Places of Worship" under the Urban Redevelopment Authority (URA)'s masterplan. These plots of land are reserved for, and assigned to, different religious groups, based on factors such as "the distribution of existing places of worship, ease of access for the community, and the potential impact on the surrounding area" (Woods 2018, p. 539). Parcels of land are auctioned off in closed bids, after which, successful bidders are allowed to use them for the construction of religious structures. Woods (2018) argues that this spatial regulation of religion protects against inter-religious group competition for space that may potentially negatively impact religious harmony in Singapore.

The outcome of this spatial regulation of religion is what Kong (2001) refers to as "official" sacred spaces-"churches, temples, synagogues, and mosques [that] illustrate the power of the secular in defining the location of religious buildings" (Kong 2001, p. 214). These "official" sacred spaces are thus religious spaces that are approved and sanctioned by secular forces, such as "rational urban planning principles, including capitalistic principles of land values and principles of multiculturalism" (Kong 2001, p. 214). Furthermore, Kong argues that the state not only has influence over religious spaces at the physical and material level, but also influence over the symbolic meaning of these "official" sacred spaces. In particular, religious structures in "official" sacred spaces "serve to endorse [the] political rhetoric about support for religion and freedom of worship, commitment to multiculturalism ... , equality of treatment, as well as religious tolerance and harmony" (Kong 1993a, p. 32) in Singapore.

While the zoning of "Places of Worship" reduces competition for space between groups of different religions, it is important to note that this simultaneously increases competition for space between 
groups of the same religion (Woods 2018). As a result, religious groups that fail to secure "official" sacred spaces-typically due to inadequate funds-often explore other innovative ways of acquiring space for the sacred. According to Kong, these "unofficial" sacred spaces include indigenous sacred sites, roadside shrines, domestic shrines, and other secular spaces used for worship (Kong 2001, 2002). Sinha (2016) also points out that these "less formalized" places of worship-religious structures along pathways, roads, and railway tracks or under trees-have always existed in Singapore's history in various forms and across diverse religious traditions, but were only labelled as "unauthorized" and "unsanctioned" when they became a hindrance to, and stood in the way of, urban renewal projects in the 1970s. On the contrary, religious sites and structures that were not "problematic" for urban planning "escaped" the purview of bureaucratic ordering of space as a result of a "deliberate knowing non-attention" by the state. In other words, places of worship that were not labelled as "illegitimate" merely gave an "impression that authorities [were] unaware of their existence" (Sinha 2016, p. 469), but not that they actually eluded the state's gaze. Thus, the strategies through which religious practitioners operating in "unofficial" sacred spaces often employ to produce and sustain sacred space are deeply textured by this complex relationship between them and the state.

If "official" sacred spaces serve to endorse the state's official narrative on religion in Singapore, "unofficial" sacred spaces then symbolize the resistance, contestation, or negotiation of official state narratives. Heng (2015) argues that the temporary roadside altars and shrines set up during the Hungry Ghost Festival serve as reified spiritual spaces that allow alternative narratives of ethnic identity to be expressed, thus subverting the monolithic notion of "Chinese-ness" imposed by the state. Heng's subsequent work on Chinese spirit mediums operating in "unofficial" sacred spaces also demonstrate how spirit mediums use aesthetic markers and bodily comportment to "subvert and resist Singapore's functionalist political ideology on religious buildings and spaces" (Heng 2016, p. 215).

The scholarly implications of what has been discussed thus far are two-fold. First, it illustrates the importance of looking beyond "official" sacred spaces as the object of inquiry and to include "unofficial" sacred spaces, as well (Dora 2018; Kong 2001; Sinha 2016). In Singapore, relevant work has been done by Kong (2002), who looked at the secular spaces used for worship, such as residential spaces turned into house churches; Sinha (2016), who tracked sacred indicators that were "inserted", "embedded", and "infused" into everyday secular urban spaces, such as hawker centers and carparks; and Heng (2016), who studied the practice of Chinese spirit mediumship in Housing Development Board (HDB) flats ${ }^{1}$ that were converted into sintuas.

Second, bringing "unofficial" sacred spaces to scholarly attention makes apparent the various strategies and techniques used to produce and sustain "unofficial" sacred spaces, as a response to the regulation of religious space by the state, which in turn complicates the conceptual notion of "sacred space" to begin with. For instance, Kong argues that the concept of "sacred space" can be negotiated by maintaining the boundary between the sacred and the secular through the politics of inclusion and exclusion (Kong 2002), or by de-emphasizing the "sacredness" of religious structures, while re-emphasizing that "sacredness" is found within the community instead (Kong 1993b). Tong and Kong (2000) also demonstrated that individuals often invent new rituals and visually re-define "sacred space" to circumvent the constraints and restrictions brought about by urban redevelopment. Finally, in her ethnography of sacred indicators in everyday secular urban spaces, Sinha argues that "religious practitioners can and do negotiate the constraints of urban, cosmopolitan, multi-ethnic and bureaucratic milieus in a variety of creative modes" (Sinha 2016, p. 484), to make space for their religious needs, often resulting in places of worship that defy neat binaries of "sacred/profane", "public/private" and "legal/illegal". In other words, the understanding of the production of sacred space within the category of "unofficial" sacred space itself requires a contextualized and nuanced approach.

1 An HDB flat is a public residential development that comes under the purview of the Housing and Development Board (HDB), which is the statutory board responsible for public housing in Singapore. 


\section{4. “Expanding" Sacred Space While Maintaining Low Profile: A Conundrum Faced by Sintuas}

In Singapore, the term "sîntúa" (the Hokkien term for 神), typically refers to a "temple" located within an HDB flat, often with a spirit medium or "tângkī" (the Hokkien term for 乩童), ${ }^{2}$ who trances a deity in order to provide devotees with spiritual assistance in various aspects of their lives, such as their health, employment, luck and wealth, relationships, or even supernatural encounters. Some of the more commonly worshipped deities by sintuas include the Monkey God or Qi Tian Da Sheng (pinyin for 齐天大圣), Guan Di (pinyin for 关帝), Guan Yin (pinyin for 观音), Tua Di Ya Peh (the Hokkien term for 大二爷伯), Shan Can Tong Zi (pinyin for 善财童子), and Lian Hua San Tai Zi (pinyin for 莲花三太子).

To the uninitiated, a sintua may look like any typical HDB flat, apart from perhaps some religious paraphernalia or banners and tablets (with the name of the sintua) placed outside the flat to indicate that the flat is a sintua. Some sintuas may also place a black command flag (or orh leng, the Hokkien term for 黑令) emblazoned with the Taoist eight trigrams outside the flat (see Figure 1). According to Chan (2006), the black command flag represents the celestial army attached to the main deity of the temple, and its presence is a strong indicator that a tangki operates within. Scholars have characterised tangkis as associated with "Shenism", which refers to the practice of worshipping spirits or "shen" (拜神) (Elliot 1955); "Chinese religion", which refers to a hybrid and syncretic blend of Taoism, Buddhism, and Confucianism (Dean 2019; DeBernardi 2006), as well as Chinese folk religion (Chan 2006). As Heng (2016) puts it, "spirit mediums are bricoleurs that may have unique variations to their practices, but nonetheless are part of a widely shared cosmology and theodicy" (DeBernardi 2006, p. 9; Heng 2016, p. 222).

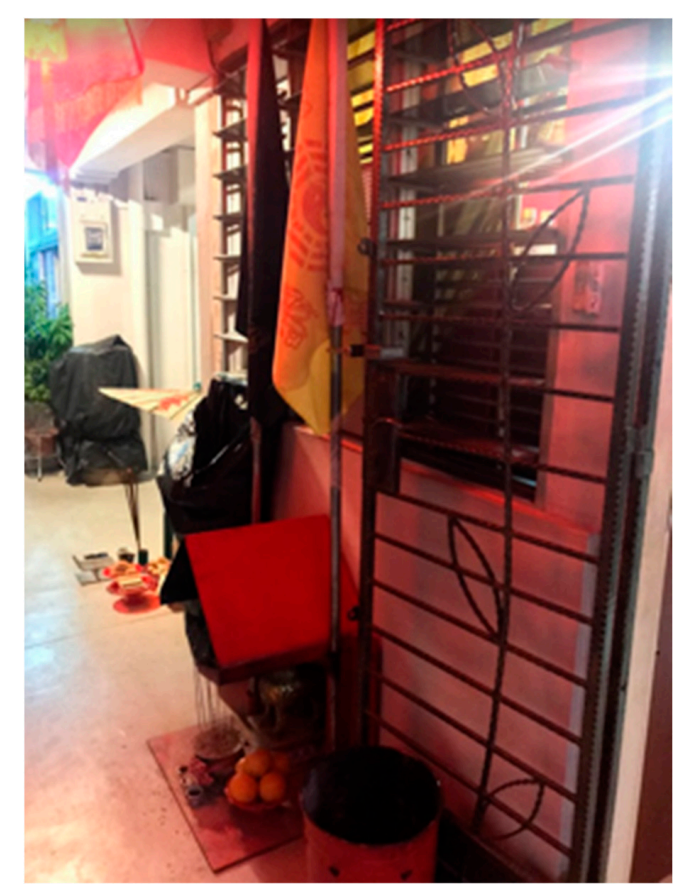

Figure 1. The Outside of a Sintua Housed in a Typical Three-room HDB flat. A black command flag can be seen outside the flat, indicating that a tangki operates within this sintua. The presence of other features, such as the red banner (at the top of the picture), a small altar on the ground, and other religious paraphernalia, may also suggest that a flat is used for religious purposes.

2 However, not all sintuas have spirit mediums. One sintua that I visited continued its operations even after the spirit medium had passed away several years before. A Taoist priest, whom the spirit medium had "approved" before passing on, now performs the necessary rituals during important religious occasions. 
According to the Taoist Federation, ${ }^{3}$ there are as many as 2000 sintuas open to devotees in Singapore (Zaccheus, Melody 2013). Some of the main activities sintuas engage in include regular spiritual consultation sessions for devotees (e.g., every 1st and 15th of the lunar month, or on every fixed day of the week), occasional major events such as the birthdays of their deities-also known as "da ri zi" (pinyin for 大日子)—as well as important religious occasions, such as the Hungry Ghost Festival.

\subsection{Sintuas Face Spatial Constraints}

The passing of the Land Acquisition Act in 1966 allowed the state to perform large-scale compulsory land acquisition for public development, and religious space in Singapore became more closely regulated by the state. Many places of worship that (literally) stood in the way of urban renewal projects gained an "illegitimate" status overnight (Sinha 2016). With the implementation of allocating "Places of Worship" to religious groups to auction for in closed bids, a temple's financial resources became a key factor in determining whether it could obtain an "official" plot of land to construct "official" sacred spaces and continue its operations legitimately. Temples that were already doing well financially often could do so, while some others worked together by pooling their financial resources to bid for and occupy a single plot of land (Heng 2015; Sinha 2003). In a study on the merger of sacred spaces and places of worship, Sinha (2003) argues that the merging of places of worship is often seen as "an administrative and bureaucratic solution to a series of practical problems, such as land scarcity, inadequate funds, and other resources" (Sinha 2003, p. 489). One good example of such an endeavor is the United Temple in Toa Payoh (Zaccheus 2014).

Many of the sintuas found in HDB flats today are those that date back to the kampong ${ }^{4}$ days, but did not have enough funding to build a proper temple in "official" places of worship. In fact, some sintuas have been waiting for more than 30 years for land on which to build a temple. Nonetheless, devotees continue to maintain and care for their deities in the premise of their homes (Chai 2014). The deity proposes, the state disposes: The vicissitudes of a Chinese temple in post- 1965 Singapore, by Koh (2016) tracks the fifty-year history of a Nine Emperor Gods temple, documenting its relocations over time and examining its physical and spatial transformation from a temple to a sintua. Koh notes that the main challenges faced by sintuas when finding new premises include strict regulations on the use of land for religious purposes under URA's masterplan, and the rising property prices and costs of construction and building (Koh 2016; Kong and Yeoh 2003).

Thus, many sintuas have explored other ways to acquire more space for larger-scale religious activities (e.g., for the celebrations of deities' birthdays). For instance, an application can be made to the Singapore Land Authority (SLA) to obtain a temporary occupation license for the use of state land for one-off religious celebrations. In the event where road reserve is needed, clearance from other public authorities, such as the Land Transport Authority (LTA) would also have to be sought (Singapore Land Authority n.d.) An application can also be made to the Town Council for the use of void decks or open spaces (e.g., basketball courts or open fields) to set up temporary tentages that would be converted into makeshift temples (Heng 2016). In addition, the support of the adviser to the grassroots organizations of the constituency where the religious event is to be held must also be obtained as part of the application (East Coast-Fengshan Town Council 2019).

In response to requests from religious groups to help meet their space needs, the state has also relaxed certain regulations and allowed some flexibility in land use. In 2010, for instance, the URA revised its guidelines to allow industrial premises for religious use on a non-exclusive and limited use basis. While industrial premises were previously not allowed for religious use, these spaces can now

3 Sintuas often register themselves with the Taoist Federation. However, the Taoist Federation has also said that it does not sanction the use of the HDB flats as home shrines, and have put in continual efforts to educate owners that their practice is against the law.

4 The term "kampong" refers to the traditional villages of indigenous peoples, as well as the urban slum areas and enclosed developments within towns and cities. 
be used for religious purposes, provided that (1) religious use does not alter the primary character and function of industrial premises, and (2) industrial premises are not used exclusively for religious purposes at the expense of industrial activities (Urban Redevelopment Authority 2012).

\subsection{Sintuas Keep a Low Profile to Avoid Trouble}

However, space constraint is but one challenge faced by sintuas. Under the HDB Lease Agreement, HDB flats are meant solely for residential purposes and the use of flats for public worship is strictly prohibited, making sintuas technically illegal under HDB regulations. Such an infringement of the terms and conditions of the lease allows HDB to compulsorily acquire a flat or terminate its tenancy as a last resort (Koh 2009). While HDB has maintained that they take a serious view of non-authorized uses of their flats, HDB also added that concrete evidence that a flat has been misused must be presented before action can be taken against errant lessees (Koh 2009). This echoes Sinha's (2016) point on the state's "deliberate knowing non-attention", where public authorities often take a "close one's eyes" approach to sintuas and their activities, and intervene only when complaints have been lodged. Thus, sintuas have also learnt to avoid getting into trouble by keeping a low profile, and by minimizing conflict with and potential complaints from their neighbors. In my fieldwork, I have observed sintuas engage in different techniques to avoid getting into trouble with public authorities. For instance, one sintua set up a queue number system to manage crowds of their devotees during days where spiritual consultations are held. Temple assistants will offer to call devotees when it is nearing their turn to consult with the deity, so as to reduce overcrowding within the flat and along the common corridors. Other sintuas have also reduced the frequency of their spiritual consultation sessions, to minimize any noise and disturbances from increased human traffic.

In other words, sintuas find themselves in a predicament where they have to deal with the conundrum of "expanding" their sacred space to fulfil their religious needs, yet do so in a manner that is not obtrusive, and that allows them to maintain a low profile and visibility. This spatial precarity underpins the importance of the modes of producing sacred spaces that bear qualities of being temporary, transient, impermanent, and immaterial, as these qualities enable sintuas to better manage the conundrum that they face. In the rest of the paper, I identify four such ways, namely, (1) temporarily re-enchanting everyday urban spaces; (2) creating an atmosphere of sacredness through immaterial religious markers; (3) appropriating secular urban spaces for religious merriment; and (4) leveraging the online space to digitally reproduce the image of the sacred.

\section{Temporarily Re-Enchanting Everyday Urban Spaces}

Responding to Kong's (2001) appeal for scholarly research to go beyond "official" sacred spaces, Holloway (2003) calls for a deeper understanding of how embodied practices of the everyday contribute to the making of the sacred space, especially since "the body and bodily action [as] fundamental components of the production of sacred space has been recognised in anthropology and ritual studies for some time" (Holloway 2003, p. 1964). In this section, I argue that the embodied sacredness of a tangki allows him or her to temporarily re-enchant everyday urban spaces, offering an alternative avenue through which the temporary production of sacred space to fulfil religious needs is achieved.

My fieldwork once led me to a sintua housed in a typical three-room HDB flat located in the West of Singapore. Like many other sintuas, a bright red banner with the sintua's name printed in gold hung directly above the gates of the flat, flanked by two bright red lanterns. A black command flag also stood outside the flat. A glance into living room of the flat reveals an impressive altar that spanned the entire wall facing the flat's entrance, which was filled with the statues of various deities, as well as a myriad of religious offerings and religious paraphernalia.

That evening, the sintua celebrated the "birthday" (or qian qiu, pinyin for 千秋) of "Cheng Huang Xie Fan Jiang Jun" (pinyin for 城隍范), a pair of deities from the netherworld, similar to the more widely known pair of netherworld deities in Singapore, Tua Di Ya Peh. Unlike other instances where sintuas would rent common spaces such as void decks and basketball courts for special religious 
occasions that required more space, this particular celebration was done within the compounds of the flat. The tangki of the sintua, a 30 year old male, tranced Xie Jiang Jun during the celebration, as the narrow corridor outside the flat slowly crowded with devotees waiting in line to pay him their respects (or qing an, pinyin for 请安). Xie Jiang Jun sat in front of the altar with his eyes closed and tongue sticking out, dressed in a dark blue-colored robe patterned with gold-colored leaves, and wore a tall gold-colored headdress decorated with bright red-colored cloth balls, a distinctive headdress worn by the netherworld deities. One by one, devotees including myself were guided by the temple assistants up to Xie Jiang Jun to pay our respects, who in return, offered us a small cup of sweet tea and dotted our foreheads with a brush dabbed in red ink as a form of blessing.

Later that night, the sintua conducted a "yewkeng" (the Hokkien term for 游境), “a procession involving the tangki inspecting the boundaries of his or her territory" (Heng 2017, p. 133), by which "territory" often refers to housing estate the sintua is located within. Walking barefooted around the housing estate, Xie Jiang Jun slung a green wax paper umbrella behind his back, held a paper fan in his left hand, and a wooden tablet painted with the words “城隍” in red in his right. A temple assistant used a white wax paper umbrella marked with red wordings to shade Xie Jiang Jun throughout the yewkeng. As this was during the Hungry Ghost Festival, the yewkeng was also done to make offerings to the "hungry ghosts" wandering around the housing estate. At certain locations along the procession - such as under trees along pavements or at grass patches below HDB flats-Xie Jiang Jun would stop and point his fan in a specific direction, signaling his accompanying temple assistants to put together a small set of offerings, comprising red candles, joss sticks, small packets of tea leaves and biscuits, as well as a stack of joss paper (see Figure 2). Devotees would then stand in front of the offerings with joss sticks in hand, paying respects to the wandering spirits in the proximity as the joss paper was set alight. Once, we stopped along a rain canal, when Xie Jiang Jun faced the bottom of the canal and spoke to "something" not visible to the rest of us, and then waved his fan upwards several times, as though gesturing the wandering spirits that we have encountered to come forth and receive their offerings.

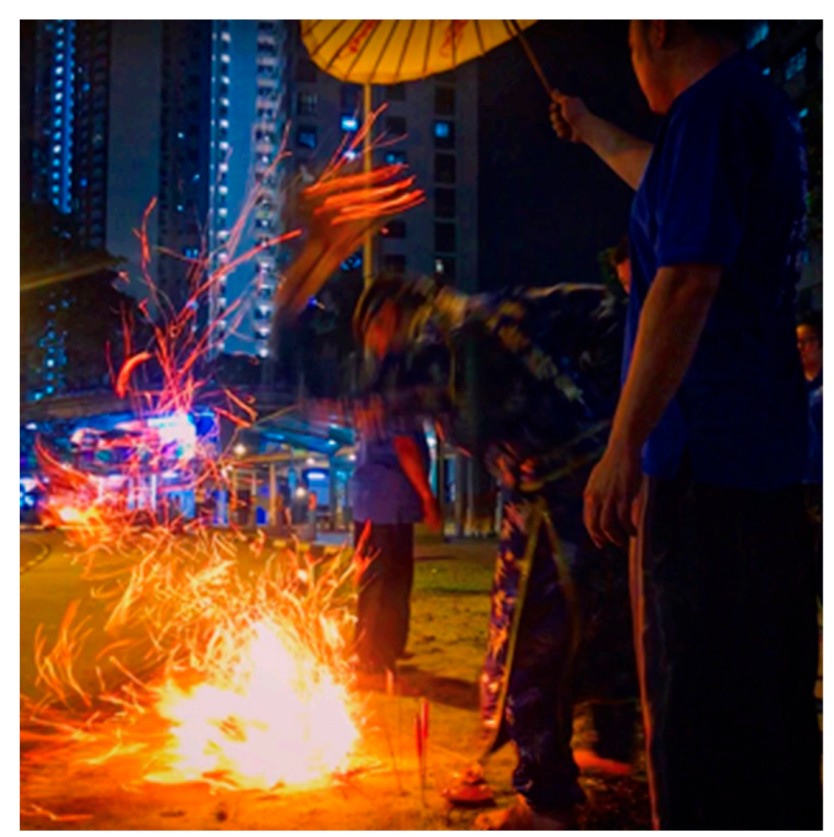

Figure 2. Offerings Set Up by the Roadside for "Hungry Ghosts" during a Yewkeng around the HDB Estate. This photo was taken near a bus stop where Xie Jiang Jun (in a blue-colored robe patterned with gold-colored leaves) stopped to instruct his temple assistants to set up a small set of offerings. A stack of joss paper was then set alight as a form of offering to the wandering spirits of the Hungry Ghost Festival. 
Weber's notion of "disenchantment" describes the character of a highly modernized and secularized bureaucratic society, where scientific explanations are more highly valued, and where processes are often oriented towards rational goals (Grosby 2013). However, this Weberian notion of disenchantment should not be conflated with "secularism", as the boundary between disenchantment and enchantment has become increasingly blurred. Scholars like Holloway (2010) argue that modernity also produces its own forms of enchantment, with ghost tourism being a good example of modern infrastructures that engineer "wonder". Instead, McEwan (2008) describes the state of enchantment as

a state in which ghosts, spirits, and spectres exist within a melange of other marvels, including magic, myth, monsters, witchcraft, sorcery, voodoo, vampires, and zombies. Such marvels are no longer thought to have been exorcised by the rational and secular processes of modernity; far from being extraneous to modernity, they are intrinsic to what are increasingly recognised as thoroughly enchanted modernities (McEwan 2008, p. 30)

In his study of how spirit mediums operate within house temples, Heng (2016) argues that the visual comportment of a spirit medium's body through behavior and the social prominence of a spirit medium produces a situation where the importance of the physical location of a sacred space is temporarily displaced, thus allowing a spirit medium to operate in any sacred space, "official" or "unofficial". Heng makes an insightful observation about the relationship between a spirit medium's embodied sacredness and the physicality of a sacred space, but I would like to push Heng's argument one step further. While Heng essentially argues that a spirit medium's embodied sacredness allows him or her to function independently or autonomously of the physical space, I argue that a spirit medium's embodied sacredness also, in turn, allows him or her to have command over the nature of the physical space, giving him or her the ability to temporarily "re-enchant" everyday urban spaces. As seen from the example described above, where Xie Jiang Jun "identifies" wandering spirits around the housing estate that devotees then make offerings to, re-enchantment occurs because the embodied sacredness of the spirit medium allows him to inject sacrality into these everyday urban spaces (a product of modern, rational, and bureaucratic spatial ordering of land by a secular state), temporarily superimposing a layer of sacred space onto these everyday lived spaces, where for a transient moment, devotees engage in ritual activities, which suggest that the living and the dead cohabit the same space (Heng 2015).

\section{Creating an "Atmosphere" of Sacredness Using Immaterial Religious Markers}

In Mapping 'new' geographies of religion: Politics and poetics in modernity, Kong (2001) argues for a need to foreground different "sensuous sacred geographies" and focus on the "aural and audio experiences and constructions of the sacred" (Kong 2001, p. 220).

One night, I was observing a spiritual consultation held in a sintua towards the end of the session. The lights in the flat were switched off and the room was dimly lit by the flames from the red candles on the altar table. The temple assistants asked if anyone else had any final questions for the deity. Getting no response, the tangki started to rock back and forth in his chair, signifying that the deity was leaving his body. Finally, the tangki slumped forward and went motionless, with a thud of his forehead on the table. One temple assistant started to call the tangki's full name repeatedly. After several attempts, the tangki regained consciousness with a sudden jerk. Immediately after, the lights in the flat were abruptly switched on, instantly lifting the mood and atmosphere of the sintua. This particular experience led to closer attention being paid to the role of immaterial religious markers, such as sounds and smells, play in creating an "atmosphere" of the sacred space.

In his work on the Hungry Ghost Festival in Singapore, Heng (2015) argues that temporary roadside altars and shrines function as "transient aesthetic markers" that reify the imaginary spiritual realm, allowing individuals to temporarily overlay spiritual and sacred space onto the physical and material space. These aesthetic markers are transient and fleeting, because they "disappeared" within the next few days after they have been cleaned up by janitors employed by the town councils. Heng also argues that their transient and impermanent nature allowed a subversion of state narratives to 
occur without being directly confrontational or immediately appearing to be subversive. Drawing upon Heng's work, I argue in this section that immaterial religious markers such as sounds and smell also allow an overlaying of spiritual and sacred space, by creating an "atmosphere" of a sacred space, despite not being reified.

\subsection{Sounds}

Existing scholarly work in both religion studies and ethnomusicology studies have established the importance of music and ritual sounds in religious practices. For instance, So (2018) talks about music; both vocal (e.g., chanting and singing) and instrumental (e.g., played with musical instruments or ritual tools)—“fa qi" (pinyin for 法器)—as an integral part of Taoist rituals. Such ritual sounds have the power to "call forth deities, exorcise evil forces, and manipulate both deities and demos" (Pregadio 2008, p. 412), and are, in essence, an outward expression of religious Taoism (Tsao and Shi 1992). Chan (2006) also illustrates the importance of ritual music in tangki worship, and describes the accompanying music as "cacophonous", representing "the martial sounds of drums in battle, produced as an invocation of the exorcistic power of thunder" (Chan 2006, p. 90).

In the yewkeng with Xie Jiang Jun mentioned earlier, simple ritual sounds made by hitting a small gong, striking a wooden block and shaking an abacus, were produced throughout the procession around the housing estate. Two female temple assistants-one bearing the abacus and the other bearing the wooden block and gong-walked at the front of the procession, and diligently maintained the sequence each "instrument" was "played", keeping to a consistent rhythm and tempo throughout their "performance". The order of the ritual sounds starts with the gong, followed by the wooden block, and ending with the abacus, before the cycle repeats itself. At one point during the yewkeng, a group of middle-aged devotees became engrossed in their own conversations, without realizing that their volumes were getting loud. They were quickly shushed by other devotees, suggesting that the soundscape that accompanied the procession was integral to creating an "atmosphere" of sacredness that should be maintained throughout the ritual.

\subsection{Smells}

Similar to sounds, smells also play an important role in creating an "atmosphere" of sacred space. In his book, Scents and scent-sibilities, Low (2008) argues that smell and odor function as social and cultural boundary markers that are associated with meanings, values, and symbolic associations. Smells thus allow for the differentiation between "us" versus "them", and mediate social interactions by inducing either social distance or social intimacy.

The role of smell—in particular, the smell of incense smoke—can be illustrated in another fieldwork encounter of mine at a sintua that worshipped the Nine Emperor Gods. For the purpose of the Nine Emperor Gods festival, a tentage was set up by the sintua at a nearby basketball court that was transformed into a temporary makeshift temple. On the sixth day of the ninth lunar month, the sintua held a vegetarian "nine table feast" for the deities. On top of having plates of vegetarian delicacies, each of the nine tables also had a censer in which kemenyan incense cups were burnt to cleanse the temple (Shen Xian Gong 2017). The kemenyan incense cups were burnt throughout the feast, replenished as soon as they began to smolder out, suggesting the importance of incense smoke (and its accompanying smell) in creating an "atmosphere" of sacredness, and to signify that the deities were feasting (see Figure 3). Later that evening, I witnessed two police officers arrive at the temple, saying that they had received complaints from nearby residents about the overwhelming incense smoke. 


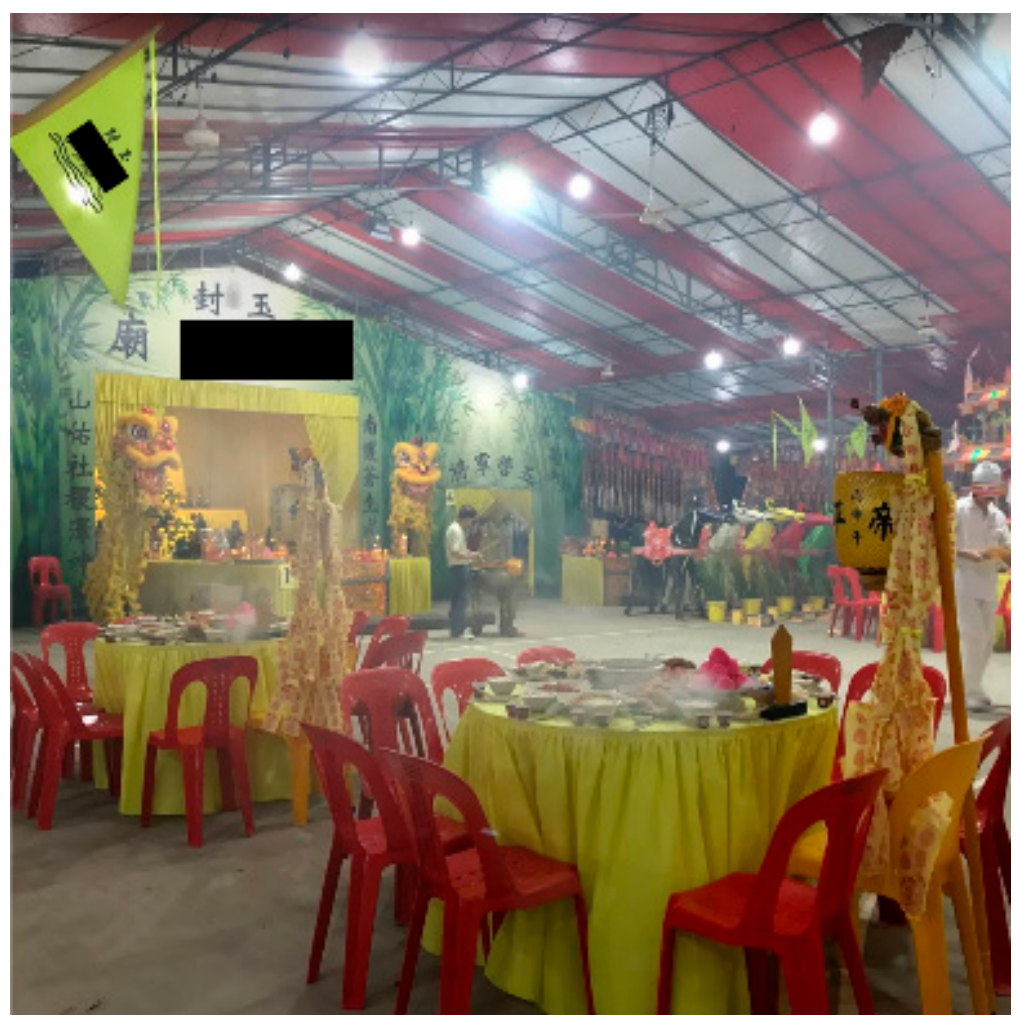

Figure 3. A Vegetarian "Nine Table Feast" for the Nine Emperor Gods at a Makeshift Temple. Kemenyan incense cups were burnt to cleanse the temple, creating an "atmosphere" of sacredness. The name of the sintua has been redacted to protect its anonymity.

In short, immaterial religious markers like sounds and smells play a role in creating an "atmosphere" of sacredness, because they have a function in religious rituals and their sensorial experiences are imbued with religious meanings and social significance. This "atmosphere" of sacredness created by immaterial religious markers temporarily adds a layer of sacred space onto the physical space before dissipating, similar to Heng's (2015) argument about the function of transient aesthetic markers in reifying an imagined spiritual space. Furthermore, it becomes apparent that sounds and smells play a role in creating an "atmosphere" of scaredness when the boundary between the "sacred" and the "profane", marked by sounds and smells, is transgressed. In his study on technology and the production of Islamic space, Lee (1999) argues that the technologically amplified Islamic call to prayer creates an immediate Islamic presence for a larger, more dispersed community, scattered as a result of the urban re-organization of Singapore's social space. Similar to sounds, smells of incense smoke also transcend corporeal boundaries and resist containment within the physical space (Tan 2013). The sounds and smells involved in religious rituals performed by sintuas mark the boundary between the "sacred" and the "profane", but exceed conventional geographical parameters, and have a far-reaching presence beyond the physical location that is produced, creating extended spatial relationships between the producer and the recipient (LaBelle 2010). The examples where noisy devotees were shushed and where residents complained about the incense smoke are instances when the boundary between the sacred and the profane is transgressed, thus making it apparent that sacred space is produced through immaterial markers like sounds and smells (Elison 2018).

\section{Appropriating Secular Urban Spaces for Religious Merriment}

In Appropriating the city: Space, theory, and bike messengers, Kidder (2009) argues that "because space is not only determining, but can also be determined, space, as it is lived, can be appropriated by the user against intended conceptions" (Kidder 2009, p. 310). In this section, I illustrate one instance where sintuas appropriate everyday urban spaces (e.g., a footpath) for their religious use, and highlight 
the significance of this form of expanding sacred space in the context of Singapore, as well as areas of future research.

One of my fieldwork encounters involved observing and participating in a "ritual-like" activity, similar to what Wang (2016) identifies as an "Ah Peh Party", a colloquial term used to describe the religious gathering of tangkis trancing a generic group of netherworld deities-such as Tua Di Ya Peh or Qi Ye Ba Ye (pinyin for 七爷八爷). The “Ah Peh Party" is typically characterized as one that is filled with "religious merriment", where the deities get to enjoy cigarettes, tea, and alcohol, and make merry conversations among themselves and their devotees. That night, two tangkis (trancing the netherworld deities 七爷公 and 六殿大哥) from a sintua located in the Northwest of Singapore, visited another sintua located in the West to pay their respects, or to “jin xiang" (pinyin for 进香). These two sintuas have, over time, built strong ties between themselves, and established a tradition where one sintua would often participate in the other sintua's major religious activities. That night's visit was part of a series of religious activities organized during the Hungry Ghost Festival.

Due to a lack of space within the HDB flat itself (as temple assistants and devotees from both sintuas had participated), the religious gathering of the deities was done along the footpath, just in front of the HDB block that the sintua was located in. At one spot along the footpath, a small altar with an incense urn, two red candles, and some offerings had been set up. Beside it was a small table that had stacks of disposable Styrofoam cups, a hot flask of tea, several cans of beer, and a bottle of Martell. With cars and buses passing by every so often, the three deities sat on simple wooden benches placed on the footpath as they smoked their pipes, sipped their beverages, and spoke to each other with smiles on their faces. Their temple assistants stood close by, fanning them in the sweltering night, attending to their needs by doing things like wiping perspiration off their faces and replenishing their cups with tea. About 30 devotees, including myself, gathered around to watch the deities in their religious merriment (see Figure 4).

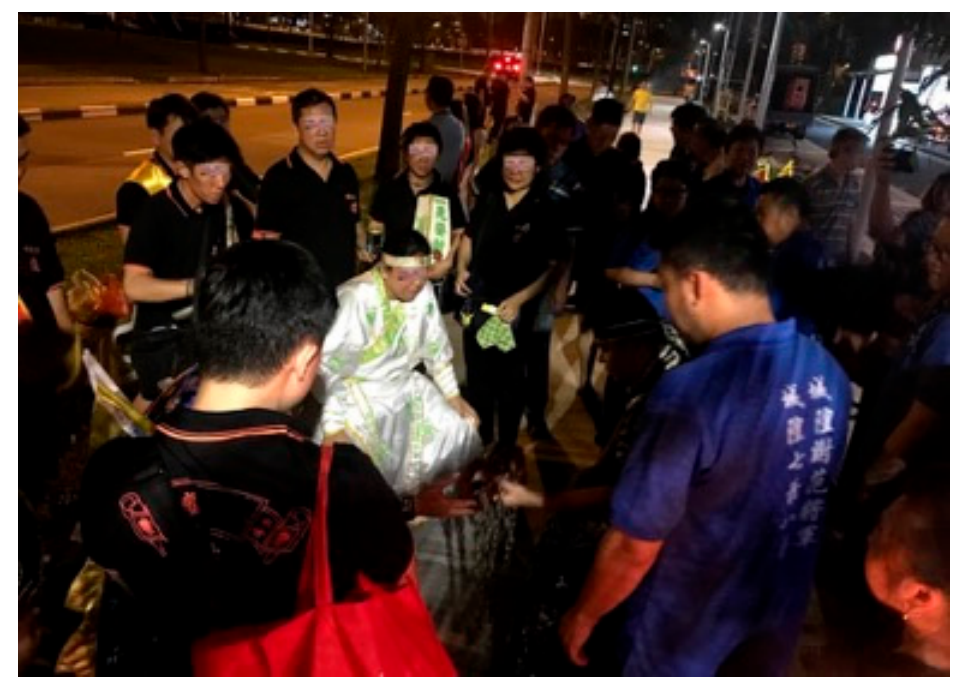

Figure 4. A Footpath being Appropriated by Two Sintuas for an "Ah Peh Party". Temple assistants and devotees from both sintuas crowd around the deities to listen in on their conversations and to join in the religious merriment. The name of the sintua has been redacted, and the faces of people have been pixelated to protect their anonymity.

Later, the tangki trancing Qi Ye stood up from his bench, pointed at a middle-aged man at the back of the crowd, and gestured him to come forward. Qi Ye poured from the bottle of Martell he was holding in his hand into a cup, and offered it to the man saying that it was "tea". The man was all smiles for being picked by Qi Ye, and jokingly questioned Qi Ye if it was indeed "tea" in the cup. Qi Ye nodded with a big smile and told him to finish his "tea" in a single gulp. I was the next lucky person Qi Ye offered his cup of "tea" to. After the session, the temple assistants packed up the 
tables and benches that they brought with them, and the footpath looked as though the gathering had never happened.

Hee and Ooi (2003) argue that public spaces are essentially constructs of the state's spatial planning, and are thus politically charged, as these spaces serve as a reification of the dominant state ideology. In this instance, the appropriation of an everyday urban space, like a footpath, by sintuas can be read as a temporary contestation of the state narrative of maintaining secularism in shared spaces, and that religion should ideally be relegated to the private sphere. Furthermore, Hee and Ooi (2003) also argue that the streets of modern Singapore project an image of centralized urban planning, designed to be simple, functional, and efficient in catering for smooth motorized and human traffic flow. Thus, the appropriation of a footpath by sintuas in this instance can also be regarded as a temporary contestation of the modern image of Singapore portrayed by the state.

However, besides appropriating the physical space of a footpath, questions about what other "appropriations" are made in such instances could also be raised. In her study on house churches in Singapore, for instance, Kong (2002) argues that the appropriation of the state's ideological values-e.g., "family", as the basic building block of society and "community before self"- by religious groups served as a useful strategy for them to avoid relocation and maintain a sacred space, in the context of a secular state (Kong 2002). In this case, it is interesting to note that, while the gathering of deities is undoubtedly a religious one, the activity also has strong non-religious overtones of "community building", as demonstrated by the maintaining of community ties between the two sintuas. Borrowing from Chan's (2006) idea of tangki worship as "communal theatre", aspects of community building can also be seen from devotees who had gathered round to observe this religious merriment. As Chan (2006) argues, "tangki events bring people together, binding them with group identity and purpose. People derive social position from participation in such activities, whether mediums, ritual assistants or devotees" (Chan 2006, p. 114). Thus, future research could potentially look into whether, and how, such overtones of "community building" resonate with another dominant state narrative- the role of public spaces as communal spaces to promote conviviality among people-as well as the implications on the concept of "sacred space".

\section{Leveraging the Online Space to Digitally Reproduce the Image of the Sacred}

In Mapping 'new' geographies of religion: Politics and poetics in modernity, Kong (2001) also argues that, with new technological developments, the intersection between religion and technology requires greater examination to shift the current focus of constructions of the sacred, and to examine how conceptions of sacred spaces alter with modernity and technology (Kong 2001). For instance, Hackett (2006) notes that religious practices are increasingly being facilitated by computer-mediated communications, where religious practitioners share information and interact with their followers, to the point where the online space has become a significant ritual location (Hackett 2006). Walker (2010) also found the existence of sacred space within cyberspace by demonstrating that MySpace qualified as analogous to offline sacred spaces, in terms of its functionality to it users (Walker 2010). Another study on how social media influences participation in the activities of Chinese folk temples found that social media enables Chinese folk temples to increase their visibility by posting and sharing real-time information, and attract potential followers to participate in their religious activities to overcome the reducing number of believers due to urbanization and generation gaps. More importantly, social media was also used by Chinese folk temples as a promotional tool to reinforce deity identity and to promote a sense of intimacy among its followers (Wang 2015).

Responding to Kong's (2001) point that "the key questions surrounding the development of cyberspace are not necessarily about whether cyberspace constitutes 'space' ... but about what this form of technology is doing to conventional conceptions of and actions in space" (Kong 2001, p. 222), I argue, in this section, that the leveraging of social media platforms like Facebook by sintuas deserve attention-especially in future research-because the digital reproduction of the image of the sacred can be read as an attempt to solidify visibility, and thus the sacred space of sintuas within 
cyberspace. Cyberspace offers itself as a viable alternative for sintuas to increase visibility, as the potential consequences are lower as compared to them doing the same in the real world, where sintuas often keep a low profile to avoid getting into trouble.

Facebook is one of the more popular social media platforms; it is widely used by the four sintuas in my study. One possible reason is Facebook's versatility in allowing the hosting of myriad content types, ranging from text, images, and videos, to the live streaming of religious activities and the creation of event pages for important religious events. The content posted on sintuas' Facebook pages can be broadly categorized into-(1) documenting religious rituals and activities (see Figure 5); (2) updating followers on upcoming religious activities and providing detailed information about these programs; and (3) live streaming major religious events to provide devotees with an alternative platform to interact with the sacred remotely (see Figure 6).

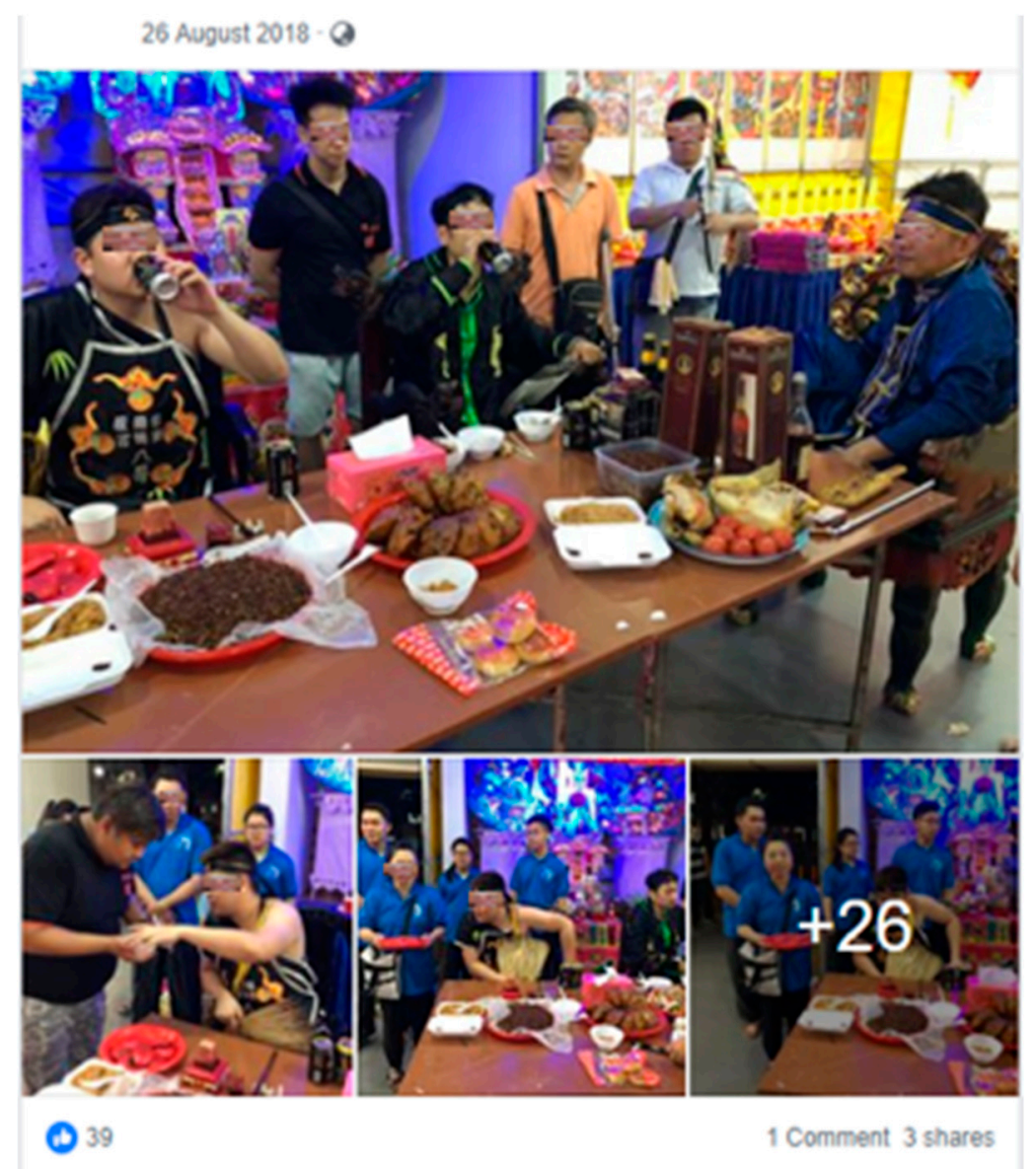

Figure 5. A Facebook Post Containing Photographs from a Sintua's Celebration of their Deity's Birthday. The photos here show the deities enjoying the religious merriment with each other, and interacting with their devotees as well. The faces of people have been pixelated to protect their anonymity.

In short, physical space helps to materialize religion, by creating opportunities for religious expressions (Woods 2018). In Mapping cyberspace, Dodge and Kitchin (2001) argue that the online space provides alternative spaces in response to placeless-ness in physical space, and "presents the opportunity to engage with and construct a new spatiality, one in part divorced from real space" (Dodge and Kitchin 2001). While sintuas are technically not "placeless" or entirely devoid of real space, the significance of such an interpretation is that the online space allows for the fulfilment of what cannot be achieved offline (i.e., expanding sacred space) and at lowered costs. The online activities engaged by sintuas suggest an attempt to digitally reproduce the image of the sacred in cyberspace, reinforcing not just a deity's identity (Wang 2015), but also the sintua as a sacred space. This can also be 
read in relation to the challenges faced by sintuas in the real world, where sintuas face the conundrum of having to expand their sacred space, yet maintain a low profile and visibility to stay out of trouble. Thus, the move to leverage online spaces can be seen as exploiting an alternative avenue to digitally solidify the visibility and sacred space of a sintua, without potentially incurring the penalties that they might face if the same had been done in the real world.
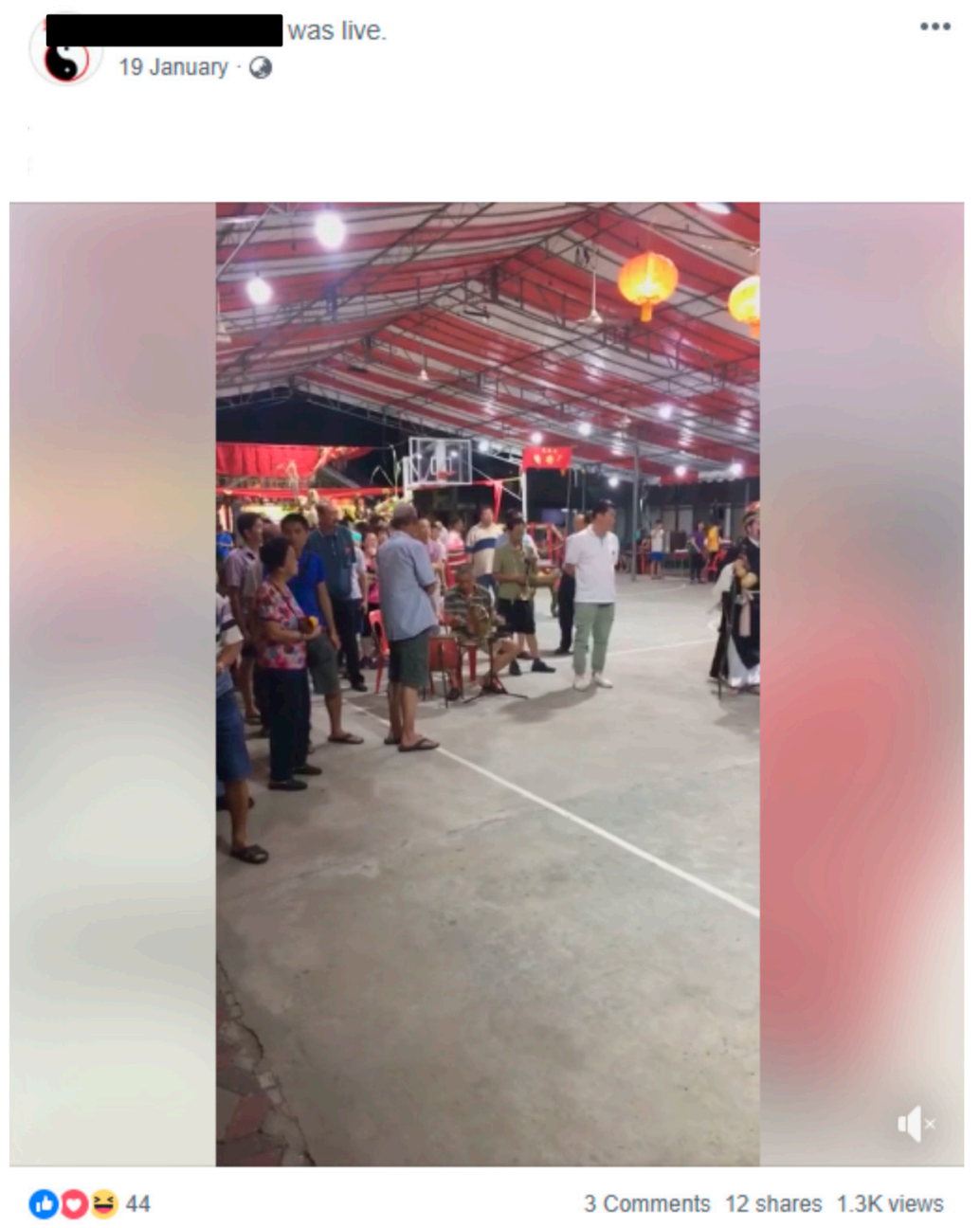

Figure 6. Facebook Live Streaming of the Celebration of a Deity's Birthday. This Facebook Live Stream was started by one of the temple assistants during the celebration of the deity's birthday. The name of the sintua has been redacted to protect its anonymity.

\section{Conclusions}

In summary, I illustrated four different ways through which sintuas produce and expand sacred space in response to spatial constraints imposed by the state. I have also highlighted certain theoretical implications that these modes of producing sacred space have on the concept of "sacred space", as well as point out potential areas for future research. While this paper neither suggests that these ways of producing sacred space apply to all sintuas in Singapore, nor claims that they are only unique to sintuas, I have attempted to demonstrate how the unique socio-political milieu sintuas are situated within (i.e., their spatial precarity) highlights the importance of focusing on the means of producing sacred spaces that bear qualities of being temporary, transient, impermanent, and immaterial, as such qualities enable sintuas to better manage spatial challenges. Future research looking at the production of sacred space should go beyond rigid binaries of "official"|"unofficial" sacred space and "sacred"|"profane", and adopt more contextualized approaches to understand "sacred space" and its production. 
Funding: This research received no external funding.

Conflicts of Interest: The author declares no conflict of interest.

\section{References}

Chai, Hung Yin. 2014. One-Stop Centre for Home Temples? Asia One, April 14. Available online: https: //www.asiaone.com/singapore/one-stop-centre-home-temples (accessed on 12 February 2019).

Chan, Margaret. 2006. Ritual Is Theatre, Theatre Is Ritual: Tang-Ki Chinese Spirit Medium Worship. Singapore: Singapore Management University, ISBN 981248115X.

Dean, Kenneth. 2019. Spirit mediums and secular-religious divides in Singapore. In The Secular in South, East, and Southeast Asia. Edited by Kenneth Dean and Peter Van der Veer. Basingstoke: Palgrave Macmillan, pp. 51-82. [CrossRef]

DeBernardi, Jean. E. 2006. The Way That Lives in the Heart: Chinese Popular Religion and Spirit Mediums in Penang, Malaysia. Palo Alto: Stanford University Press, ISBN 978-0804752923.

Dodge, Martin, and Rob Kitchin. 2001. Mapping Cyberspace. London: Routledge, ISBN 0415198836.

Dora, Veronica Della. 2018. Infrasecular geographies: Making, unmaking and remaking sacred space. Progress in Human Geography 42: 44-71. [CrossRef]

East Coast-Fengshan Town Council. 2019. Terms and Conditions for Use of Designated Common Property. Available online: https://ectc.org.sg/wp-content/uploads/2019/09/tnc-useofcommonareas.pdf (accessed on 12 February 2019).

Elison, William. 2018. The Neighborhood of Gods: The Sacred and the Visible at the Margins of Mumbai. Chicago: University of Chicago Press, ISBN 9780226494906.

Elliot, Alan John Anthony. 1955. Chinese Spirit Medium Cults in Singapore. London: Department of Anthropology, London School of Economics, ISBN 9780485195149.

Geertz, Clifford. 2008. Thick description: Toward an interpretive theory of culture. In The Cultural Geography Reader. Edited by Timothy Oakes and Patricia L. Price. Abingdon: Routledge, pp. 41-51. [CrossRef]

General Household Survey. 2015. Department of Statistics, Singapore. Available online: https://www.singstat.gov. sg/-/media/files/visualising_data/infographics/ghs/highlights-of-ghs2015.pdf (accessed on 20 February 2019).

Goh, Daniel P. S. 2016. Secular space, spiritual community and the hybrid urbanisms of Christianity in Hong Kong and Singapore. International Sociology 31: 432-49. [CrossRef]

Grosby, Steven. 2013. Max Weber, religion, and the disenchantment of the world. Society 50: 301-10. [CrossRef]

Hackett, Rosalind I. J. 2006. Religion and the Internet. Diogenes 53: 67-76. [CrossRef]

Hee, Limin, and Giok Ling Ooi. 2003. The politics of public space planning in Singapore. Planning Perspectives 18: 79-103. [CrossRef]

Heng, Terence. 2015. An appropriation of ashes: Transient aesthetic markers and spiritual place-making as performances of alternative ethnic identities. The Sociological Review 63: 57-78. [CrossRef]

Heng, Terence. 2016. Making "unofficial" sacred space: Spirit mediums and house temples in Singapore. Geographical Review 106: 215-34. [CrossRef]

Heng, Terence. 2017. Visual Methods in the Field: Photography for the Social Sciences. Abingdon: Routledge, ISBN 978-1317609629.

Holloway, Julian. 2003. Make-believe: Spiritual practice, embodiment, and sacred space. Environment and Planning A: Economy and Space 35: 1961-74. [CrossRef]

Holloway, Julian. 2010. Legend-tripping in spooky spaces: Ghost tourism and infrastructures of enchantment. Environment and Planning D: Society and Space 28: 618-37. [CrossRef]

Kidder, Jeffrey. L. 2009. Appropriating the city: Space, theory, and bike messengers. Theory and Society 38: 307-28. [CrossRef]

Koh, Keng We. 2016. The deity proposes, the state disposes: The vicissitudes of a Chinese temple in post- 1965. In Singapore: Negotiating State and Society, 1965-2015. Edited by Jason Lim and Terence Lee. Abingdon: Routledge, pp. 142-58. ISBN 978-1138998650.

Koh, Maureen. 2009. Small Shrine in Medium's Flat. Asia One, September 22. Available online: https://www.asiaone. com/News/The\%2BNew\%2BPaper/Story/A1Story20090921-169022.html (accessed on 12 February 2019).

Kong, Lily, and Brenda S. A. Yeoh. 2003. The Politics of Landscapes in Singapore: Constructions of" Nation". Syracuse: Syracuse University Press, ISBN 0815629613. 
Kong, Lily. 1993a. Ideological hegemony and the political symbolism of religious buildings in Singapore. Environment and Planning D: Society and Space 11: 23-45. [CrossRef]

Kong, Lily. 1993b. Negotiating conceptions of 'sacred space': A case study of religious buildings in Singapore. Transactions of the Institute of British Geographers 18: 342-58. [CrossRef]

Kong, Lily. 2001. Mapping 'new' geographies of religion: Politics and poetics in modernity. Progress in Human Geography 25: 211-33. [CrossRef]

Kong, Lily. 2002. In search of permanent homes: Singapore's house churches and the politics of space. Urban Studies 39: 1573-86. [CrossRef]

LaBelle, Brandon. 2010. Acoustic Territories: Sound Culture and Everyday Life. London: Bloomsbury Publishing, ISBN 978-1441161369.

Lai, Ah Eng. 2004. Beyond Rituals and Riots: Ethnic Pluralism and Social Cohesion in Singapore. Singapore: Marshall Cavendish, ISBN 9812102728.

Lee, Tong Soon. 1999. Technology and the production of Islamic space: The call to prayer in Singapore. Ethnomusicology 43: 86-100. [CrossRef]

Lim, Francis Khek Gee. 2012. The eternal mother and the state: Circumventing religious management in Singapore. Asian Studies Review 36: 19-37. [CrossRef]

Lopes, Katia Batista. 2016. An Ethnography of Global Connections: The Case of Critical Mass. Masters dissertation, Department of Anthropology, University of the Witwatersrand, Johannesburg, South Africa, March. Available online: http://wiredspace.wits.ac.za/bitstream/handle/10539/22807/research\%20Katia\% 20Lopes.pdf?sequence=2\&isAllowed=y (accessed on 15 February 2019).

Low, Kelvin E. Y. 2008. Scent and Scent-Sibilities: Smell and Everyday Life Experiences. Cambridge: Cambridge Scholars Publishing, ISBN 978-1443802154.

Mahizhnan, Arun, and Tsao Yuan Lee. 2002. Singapore: Re-Engineering Success. Singapore: Institute of Policy Studies, ISBN 978-812102041.

Marcus, George E. 1995. Ethnography in/of the world system: The emergence of multi-sited ethnography. Annual Review of Anthropology 24: 95-117. [CrossRef]

McEwan, Cheryl. 2008. A very modern ghost: Postcolonialism and the politics of enchantment. Environment and Planning D: Society and Space 26: 29-46. [CrossRef]

Ng, Kelly. 2017. Govt to Toughen Laws to Safeguard Religious Harmony: Shanmugam. TODAY, September 8. Available online: https://www.todayonline.com/singapore/govt-toughen-laws-safeguard-religiousharmony-shanmugam (accessed on 12 February 2019).

Ooi, Giok Ling, Sharon Siddique, and Soh Kay Cheng. 1993. The Management of Ethnic Relations in Public Housing Estates. Singapore: Institute of Policy Studies, ISBN 9812100482.

Pereira, Shane. 2016. The management of new religious movements in Singapore. In Managing Diversity in Singapore: Policies and Prospects. Edited by Mathew Mathews and Fong Chiang Wai. Singapore: World Scientific, pp. 85-118. [CrossRef]

Pregadio, Fabrizio. 2008. The Encyclopedia of Taoism. London: Routledge, ISBN 978-0700712007.

Shatkin, Gavin. 2014. Reinterpreting the meaning of the 'Singapore model': State capitalism and urban planning. International Journal of Urban and Regional Research 38: 116-37. [CrossRef]

Shen Xian Gong. 2017. Nine Emperor Gods Festival. Available online: https://nineemperorgodsproject.com/ 2018/09/29/shen-xian-gong-\%E7\%A5\%9E\%E4\%BB\%99\%E5\%AE\%AB-2017-english-version/ (accessed on 20 February 2019).

Singapore Land Authority. n.d. Rental of State Properties. Available online: https:/www.sla.gov.sg/Services/ Rental-of-State-Property-and-Land (accessed on 20 February 2019).

Sinha, Vineeta. 2003. Merging 'different' sacred spaces: Enabling religious encounters through pragmatic utilisation of space? Contributions to Indian Sociology 37: 459-94. [CrossRef]

Sinha, Vineeta. 2016. Marking spaces as 'sacred': Infusing Singapore's urban landscape with sacrality. International Sociology 31: 467-88. [CrossRef]

So, Allison Ming-Chuen. 2018. Ritual and non-ritual Daoist Music at Fung Ying Seen Koon: Their role, transmission, sustainability and challenges in Hong Kong. In Traditional Musics in the Modern World: Transmission, Evolution, and Challenges. Edited by Bo-Wah Leung Bo-Wah. New York: Springer, pp. 223-42. [CrossRef] 
Tan, Eugene Kheng Boon. 2008. Keeping God in Place: The management of religion in Singapore. In Religious Diversity in Singapore. Edited by Lai Ah Eng. Singapore: Institute of Southeast Asian Studies, pp. 55-82. [CrossRef]

Tan, Qian Hui. 2013. Smell in the city: Smoking and olfactory politics. Urban Studies 50: 55-71. [CrossRef]

Tong, Chee Kiong, and Lily Kong. 2000. Religion and modernity: Ritual transformations and the reconstruction of space and time. Social \& Cultural Geography 1: 29-44. [CrossRef]

Tsao, Penyeh, and Xinming Shi. 1992. Current research of Taoist ritual music in mainland China and Hong Kong. Yearbook for Traditional Music 24: 118-25. [CrossRef]

Urban Redevelopment Authority. 2012. Guidelines for Non-Exclusive and Limited Religious Use in Industrial Premises. June 12. Available online: https://www.ura.gov.sg/Corporate/Guidelines/Circulars/dc12-07 (accessed on 12 February 2019).

Walker, Seth. 2010. My [sacred] space: Discovering sacred space in cyberspace. The Journal of Religion and Popular Culture 22: 5. [CrossRef]

Wang, Dean Koon Lee. 2016. The ah peh party: Religious merriment and homophilous networks. Paper presented at Comparative Approaches to Inter-Asian Religious and Trade Networks, Singapore, March 3-4.

Wang, Kuo-Yan. 2015. Invitation to a deity's celebration: How social media influences participation in the activities of Chinese folk temples. Journal for the Study of Religions and Ideologies 14: 231-51.

Wolcott, Harry. F. 2008. Ethnography: A Way of Seeing, 2nd ed. Lanham: AltaMira Press, ISBN 978-0759111691.

Woods, Orlando. 2018. Spaces of the religious economy: Negotiating the regulation of religious space in Singapore. Journal for the Scientific Study of Religion 57: 531-46. [CrossRef]

Zaccheus, Melody. 2013. Up to 2000 Temples Set up in Homes. Asia One, November 20. Available online: https://www.asiaone.com/singapore/2000-temples-set-homes (accessed on 12 February 2019).

Zaccheus, Melody. 2014. Dragon Playground's United Temple: Toa Payoh's Rich Heritage. Asia One, August 18. Available online: https:/www.asiaone.com/singapore/dragon-playground-united-temple-toa-payohs-richheritage (accessed on 12 February 2019).

(C) 2020 by the author. Licensee MDPI, Basel, Switzerland. This article is an open access article distributed under the terms and conditions of the Creative Commons Attribution (CC BY) license (http://creativecommons.org/licenses/by/4.0/). 